\title{
PURSUIT FOR STRATEGIC FOREIGN TRADE MARKET
}

\author{
Volkan ONGEL \\ Alkan CELIK \\ Ilyas SOZEN
}

Beykent University, Turkey

\begin{abstract}
With the end of the Cold war and dissolution of the Soviet Union caused the termination of the trade structure between Turkey and Soviet Union. After the Soviet Union era, the newly independent states - that are out of planned economy- in Eurasia region and the trade relations that are kept with centralized management for many years started to be carried out with different states. This change affected trade relations that Turkey had with this region.

Several unions were tried to be formed over the region for the past 20-year-period. However, because of several reasons, these unions failed. Nevertheless, EURASEC that was decided to be established in 2000, has become a constitution of customs union among 3 members. In 2012 a common market will be formed among these 3 countries that increase the economy by 2 trillion U.S. Dollars and trading volume by 1 billion U.S. Dollars.

Therefore, this paper argues that EURASEC including especially Russia, Kazakhstan and Belarus common economic space would be a strategic foreign trade market for Turkey. Hence, this paper tries to analyze the goods specified trade opportunities of this market for Turkey's export potential. This paper is based on the historical analyze method and also the statistical goods specified foreign trade data of relevant countries.
\end{abstract}

Key words: Economic Integration, Trade Forecasting, EURASEC

\section{INTRODUCTION}

During the Cold war period, countries forming the Soviet Union, maintained their social, administrational, economical, safety and energy processes within a central planning structure bound to one authority. By disintegration of the Union at the end of 1991, many independent governments have occurred in the Eurasia region. The countries that evolved their trade relations and business processes suddenly were faced with open economic conditions under central planned economy. This change directly affected trade relations between the governments of the region and Turkey. The end of the Cold war and demise of the Soviet Union changed trade relations that Turkey had with. After the Soviet Union era, the newly independent states- that are out of planned economy- in Eurasia region and the trade relations that are kept with centralized management for many years started to be carried out with different states.

In Eurasia, it is claimed that economic and political unions after the dissolution of the Soviet Union could not survive for various reasons and committed negotiation and agreements remained on paper only. Despite that, it can also be said that the development of Eurasian Economic Community was a success. That is to say; a customs union that came into force on 1 January 2010 was built among the three member nations Russia, Belarus and Kazakhstan. The aim for 2012 is the composition of common market which shall be defined as a step further in economic integration.

In this context, our study aims at analyzing possible strategically markets for Turkey's foreign trade due to changes in the region. In this respect the data on the foreign trade between Eurasec Region and Turkey area examined by historical analysis method. Empirical literature is mentioned about customs unions and economic integration theory in our study. Eurasian economic community and goods specified analysis of trade of Turkey is analyzed afterwards. Our study is completed by things needed to be performed to render governments of the region a strategically foreign trade market for Turkey.

\section{CUSTOMS UNIONS AND ECONOMIC INTEGRATION THEORY}

It is claimed that economic integration is carried out by following certain processes. In foreign trade zone is based on an agreement which provides the free circulation of goods among members there is no obstacle change of goods and quota. This is accepted as the first phase of economic integration. 
The members of foreign trade zone are able to move for their own benefit in their relations with third countries. They do not have any obligation to implement the common customs tariff towards the nonunion member states (Ertürk, 2010: 142-143). The second phase of economic integration is the customs union which includes the free change of goods among the member nations and additionally it brings a common restraint system for the trade among the non-member states (Karluk, 1996: 214).

Viner's (1950) famous book "The Customs Union Issue" is the initiator of subsequent customs union literature. Jacob Viner's Customs Union (CU) theory is directly derived from the Ricardian approach to international trade, according to which countries trade with one another because they are different. He developed what later became known as the trade creation-trade diversion approach to regional trade agreements to help in understanding this ambiguity. The Vinerian theory describes only the static, one-off benefits to be gained from forming a customs union. (Garcia, Clayton, Hobley, 2004, 142-143) The static effects of a customs union can be trade diversion or trade creation. Following Viner's work, for many years trade creating regional agreements were seen as good, and trade diverting agreements were seen as bad. (Abrego and others, 2005:120) In his analysis, Viner studied the changes in allocation of resources and production effectively and he ignored demands. Meade (1955) superimposed consumption to Viner's analysis in his work entited "The Theory of Customs Union".

The dynamic approach, supported by economists like Krugman, takes into account economic elements which were previously overlooked in the Vinerian approach, arguing that there are also dynamic gains to be achieved in a CU. Dynamic effects of a CU are the effects on GDP's growth rate in long-term. These are; i) increased competition ii) economies of scale iii) investment subsidy effect iv) effect of external economies, v) effect of technological improvement, vi) polarization effect. (Yıldırım and Dura, 2007:146)

In literature, it is seen that the description of economic integration has a general definition which includes various kinds of structures, while J. Tinbergen (1965), who did many works on that issue, states that with the international economic union, international economic cooperation should be optimized C. Kindleberger (1958) takes the definition as the equality of the cost of production elements. (Karluk, 1996:212) Nowadays generally is known that economy of separate countries should be unified in the manner that it can form an economic region (Ongel, 2010:87).

In addition to customs union, the common market which consists of free movement of the factors of production (goods, services, labour and capital) can be evaluated as the third phase. According to economic integration theory, the last phase is a kind of economic union which combines the economies of member nations in a central bank, single money and fiscal system in addition to all features. In consequence of economic union, in addition to free movement of goods and products, it is seen that it is achieved in common social and economic policies. With the rise of trade volume which is the primary aim of economic integration by means of creating an extended market, recovery, rise of living standards, remove of regional imbalances, strengthening the status of group in political and financial events around the world, finding common solutions to the problems are also important goals (K1lıc, 2002).

In order to have a successful economic integration; (Kilic, 2002)

i. member nations should have similar economic structures

ii. they should have regional proximity

iii. they should have neighbour earth proximity

iv. they should have a wide earth land

v. they should take place in union.

Because geographical proximity has a reducing effect on transportation costs, and it is argued that economical integration has more profits for the member countries. Wonnacott and Lutz (1989), Krugman (1991), Panagariya (1997), Bhagwati and Panagariya (1996), Frankel etc. (1996), Schiff (1997, 1999) Krishana (2003) studied over this issue.

vi. Group members should be their best customers and providers

vii. consisted union should be a market which has a big population

viii.union members should share in production and trade in the World is claimed as the features which rise the prospects and benefits of success of economic integration. 
Since the 1980s in the world economy there have been increasing tendencies of regionalization. European Union (EU), found on the Rome Treaty (1957) purposed the creation of a common market by the 1993, and it created not only the common market, but also achieved the economic union with a common currency EURO, and is actively moving towards the political union (Moldosanov, 2005:23).

\section{EURASIAN ECONOMIC COMMUNITY AND GOODS-SPECIFIED ANALYSIS OF TRADE OF TURKEY}

The Eurasian Economic Community (EURASEC) is an international economic organization which also created a common external border around the member countries. The Eurasec's history goes back to January 6, 1995 when Russia and Belarus signed bilateral Customs Union Agreement. On January 20, 1995, these two countries and Kazakhstan signed the trilateral Customs Union Agreement. Kyrgyzstan and Tajikistan acceded to both agreements in 1996 and 1999, respectively. With the purpose of institutionalizing the formation of customs union and the single economic space, these five countries signed the Treaty on the Establishment of Eurasian Economic Community on 10 October 2000. The Treaty entered into force on 30 May 2001. (Shadikhodjaev, 2009:559) Uzbekistan joined the Community in 2006, but left the membership in 2008. Ukraine, Moldova and Armenia have been in watchdog position since 2003 (Eurasianhome). It can also be argued that the development of Eurasian Economic Community was successful. That is to say; there is a customs union between the three member nations Russia, Belarus and Kazakhstan, which came into force on 1 January 2010. Objective for 2012 is the composition of common market which shall be defined as a further step in economic integration. This customs union formed an area was a population of seventy million and gross domestic product is a two trillion dollar. The total trade of union is about 900 billion dollar. It seems possible that by 2012 a new market will be established. When the total Eurasec region is considered, this number could increase. For the economic integration theory and empirical results, it is predicable that the union has a high chance of success (Öngel, 2010:86-88).

In 2006, a Eurasian development bank was founded with the financial support of Russia and Kazakhstan under the name of Eurasian Development Bank. In this bank, the member states including Armenia, Tajikistan and Belarus gave support other members' states during economic crises. Besides, it also contributes to the matter of removing differences between economies and making up deficiencies in infrastructures (Eurasian Development Bank). According to the current geopolitical position and the possessed energy resources, it is claimed that, there is a need of creating a single energy region in order to achieve the energy safety and association within the aims of the union and this would be an important factor in increasing the prospects of economic integration. Furthermore, it is thought that such kind of a union is necessary for Central Asia countries and that it would be an important alternative for the countries, Russia in particular, which is an unsuccessful to be a member of World Trade Organization until now (Norling and Swanstrim, 2007).

\begin{tabular}{|c|c|c|c|c|c|c|}
\hline \multicolumn{7}{|c|}{ Table 1: EURASEC Countries Macro Economic Variables } \\
\hline & $\begin{array}{c}\text { Population } \\
\text { (Million) }\end{array}$ & $\begin{array}{c}\text { GDP } \\
\text { (Billion \$) }\end{array}$ & $\begin{array}{c}\text { GDP per Cap- } \\
\text { ita } \\
\text { (PPP \$) }\end{array}$ & $\begin{array}{c}\text { Export } \\
\text { (Billion \$) }\end{array}$ & Import (Billion \$) & $\begin{array}{c}\text { Deficit } \\
\text { (Billion \$) }\end{array}$ \\
\hline Belarus & 9,5 & 53 & 13400 & 24,5 & 29,8 & $-5,3$ \\
\hline Kazakhstan & 15,5 & 131 & 12800 & 59,2 & 30,1 & 29,1 \\
\hline Kyrgyzstan & 5,5 & 4,4 & 2200 & 1,6 & 3 & $-1,4$ \\
\hline Russian & 138 & 1477 & 15900 & 376,7 & 237,3 & 139,4 \\
\hline Tajikistan & 7,6 & 5,5 & 2000 & 1,3 & 3,3 & -2 \\
\hline
\end{tabular}

The Eurasec region covers an area of more than 20 million $\mathrm{km}^{2}$. However, it has 174 million populations in total. The countries which are situated within this region will join the customs union in 2012. The Eurasec countries such as Belarus, Kazakhstan and Russia's hold per capita income of 13-16 thousand dollars. These countries have bilateral trade potential through high per capita income. The half of the Russian's 376 billion \$ generated export and sixty percent of Kazakhstan's exports which reached 60 billions $\$$, include raw materials, such as oil and natural gas (CEID Data, Russia and Kazakhstan). Increase in the prices of natural resources has led to a rise in the rates of net exports both in 
Kazakhstan and Russia. The Kyrgyzstan and Tajikistan have fewer incomes and less economic goods than other Eurasec countries. Russia and Kazakhstan have imported cotton from Kyrgyzstan and aluminum from Tajikistan. (CIA, Factbook). On the other hand, Kyrgyzstan and Tajikistan are countries which supply raw materials to Eurasec region.

\begin{tabular}{|c|c|c|c|c|c|c|}
\hline \multirow[b]{2}{*}{ Belarus } & \multirow{3}{*}{$\begin{array}{l}\text { Export } \\
\text { Import }\end{array}$} & \multirow[t]{3}{*}{ Belarus } & \multirow{3}{*}{$\begin{array}{c}\text { Kazakhstan } \\
244 \\
70\end{array}$} & \multirow{3}{*}{$\begin{array}{c}\text { Kyrgyzstan } \\
33 \\
4\end{array}$} & \multirow{2}{*}{$\begin{array}{l}\text { Russian } \\
6783\end{array}$} & \multirow{3}{*}{$\begin{array}{c}\text { Tajikistan } \\
24 \\
3\end{array}$} \\
\hline & & & & & & \\
\hline & & & & & 7110 & \\
\hline \multirow[t]{2}{*}{ Kazakhstan } & Export & 70 & & 267 & 3586 & 195 \\
\hline & Import & 244 & & 140 & 7450 & 13 \\
\hline \multirow[t]{2}{*}{ Kyrgyzstan } & Export & 4 & 140 & & 190 & 24 \\
\hline & Import & 33 & 267 & & 773 & 5 \\
\hline \multirow[t]{2}{*}{ Russian } & Export & 7110 & 7450 & 773 & & 487 \\
\hline & Import & 6783 & 3586 & 190 & & 88 \\
\hline \multirow[t]{2}{*}{ Tajikistan } & Export & 3 & 13 & 5 & 88 & \\
\hline & Import & 24 & 195 & 24 & 487 & \\
\hline $\begin{array}{l}* 2001-201 \\
\text { Source: } \operatorname{Pr}\end{array}$ & age & tt and in & $\begin{array}{l}\text { data. } \\
\text { ata }\end{array}$ & & & \\
\hline
\end{tabular}

The basic reason of the customs unions established among Belarus, Russia and Kazakhstan from 2012, can be remarked in the bilateral trade figures at table 2. Because, these three countries trade figures flows at a very low level in Tajikistan and Kyrgyzstan. As indicated in the table 2, Russia is the main hub country. Russia's bilateral trade is higher in comparison with Kazakhstan and Belarus. However, Kazakhstan and Belarus bilateral trade has started to rise in the last four years (CEIC Data, Belarus and Kazakhstan Foreign Trade Data). To establish the customs union among Belarus, Kazakhstan and Russia at 2012, this union is economically significant.

Turkey and Eurasec countries bilateral (trade) imports and exports in 1996, 2002 and 2010 are presented in table 3 as capital goods, raw materials (intermediate goods) and consumption goods. 1996 is the year which Turkey joined EU customs union, 2002 is the foundation of Eurasec Union, and 2010 displays the year after the global economic crisis. As it is known, the reason of Turkey's foreign trade deficit is in consequence import of raw materials and intermediate goods. Turkey imports replacement from EU, raw materials as oil and natural gas from Eurasec countries (TUIK, Foreign Trade Data). Turkey's foreign trade deficit with Russia and Kazakhstan is due to the rise of oil prices and "Blue Stream" obligation. Turkey's bilateral trade with Eurasec region keeps a continuous increase. Only, Turkey's capital goods export to Kyrgyzstan has decreased in fifteen years period. 
Table 3: Turkey - Eurasec Foreign Trade (US Dollars)

Capital Goods

\begin{tabular}{|c|c|c|c|c|c|c|}
\hline \multirow[b]{2}{*}{ Country } & \multicolumn{2}{|c|}{1996} & \multicolumn{2}{|c|}{2002} & \multicolumn{2}{|l|}{2010} \\
\hline & Export & Import & Export & Import & Export & Import \\
\hline Belarus & 1.666 .697 & 831.795 & 2.729 .653 & 481.196 & 17.913 .702 & 1.170 .198 \\
\hline Kazakhstan & 41.486 .394 & 1.497 .760 .277 & 27.636 .988 & 823.272 & 111.066 .198 & 440.592 \\
\hline Kyrgyzstan & 13.628 .091 & 536.687 & 2.990 .428 & 622.519 & 5.773 .422 & 76.231 \\
\hline Russian & 148.593 .407 & 21.119 .538 & 47.246 .095 & 4.373 .038 & 348.208 .485 & 47.201 .536 \\
\hline Tajikistan & 373.694 & & 401.509 & 10.688 & 5.828 .215 & 470 \\
\hline Armenia & 0 & 0 & 0 & 0 & 5.565 & 0 \\
\hline Ukraine & 18.959 .412 & 13.605 .090 & 18.948 .670 & 2.739 .369 & 94.931 .947 & 6.588 .002 \\
\hline \multirow[t]{3}{*}{$\%$ Total Trade } & 20 & 15 & 3,5 & 0,1 & 5 & 0,2 \\
\hline & \multicolumn{6}{|c|}{ Raw Materials (Intermediate Goods) } \\
\hline & \multicolumn{2}{|c|}{1996} & \multicolumn{2}{|c|}{2002} & \multicolumn{2}{|l|}{2010} \\
\hline Country & Export & Import & Export & Import & Export & Import \\
\hline Belarus & 2.625 .193 & 32.429 .192 & 11.508 .196 & 18.818 .201 & 118.324 .773 & 146.239.396 \\
\hline & & & & & & 2.469 .892 .47 \\
\hline Kazakhstan & 52.949 .562 & 99.559 .767 & 81.985 .012 & 202.386 .723 & 364.091 .169 & 8 \\
\hline Kyrgyzstan & 10.584 .703 & 5.729 .874 & 11.352 .857 & 8.418 .849 & 51.321 .685 & 12.719 .423 \\
\hline Moldova & 8.688 .039 & 14.013 .874 & 26.732 .268 & 3.560 .056 & 75.451 .347 & 94.960 .174 \\
\hline Russian & 399.625 .015 & 1.892 .029 .756 & 607.925 .713 & 3.861 .656 .440 & 2.081 .063 .835 & $\begin{array}{r}21.124 .649 .2 \\
85\end{array}$ \\
\hline Tajikistan & 640.119 & 2.781 .220 & 3.126 .689 & 40.647 .565 & 37.772 .660 & 283.649 .058 \\
\hline Armenia & 0 & 0 & 0 & 0 & 10.120 & 2.525 .488 \\
\hline Ukraine & 76.633 .268 & 736.119 .454 & 145.523 .377 & 979.040 .761 & 587.770 .595 & $\begin{array}{r}3.790 .667 .36 \\
8\end{array}$ \\
\hline$\%$ Total Trade & 6 & 10 & 6 & 12 & 6 & 21 \\
\hline
\end{tabular}

\begin{tabular}{lrrrrrr} 
& \multicolumn{7}{c}{ Consumption Goods } \\
\cline { 2 - 7 } Country & \multicolumn{1}{c}{$\mathbf{1 9 9 6}$} & \multicolumn{2}{c}{$\mathbf{2 0 0 2}$} & \multicolumn{2}{c}{$\mathbf{2 0 1 0}$} \\
\cline { 2 - 7 } Export & Import & Export & Import & Export & Import \\
\cline { 2 - 7 } Kelarus & 5.616 .074 & 4.339 .123 & 5.864 .289 & 238.490 & 50.580 .586 & 1.030 .503 \\
Kyrgyzstan & 69.632 .092 & 498.791 & 50.045 .440 & 641.629 & 485.341 .288 & 45.148 .524 \\
Moldova & 22.887 .471 & 131.351 & 9.600 .627 & 8.581 .196 & 99.847 .908 & 39.961 \\
Russian & 3.611 .018 & 405.700 & 11.102 .885 & 968.434 & 59.378 .142 & 15.701 .812 \\
Tajikistan & & & & & & \\
\hline Ukraine & 961.512 .573 & 7.989 .824 & 516.863 .289 & 25.599 .748 & 2.191 .525 .905 & 376.215 .012 \\
\hline \% Total Trade & 3.430 .339 & 4.506 & 7.387 .104 & 37.664 & 68.966 .525 & 12.929 .524 \\
\hline
\end{tabular}

Source: TUIK Data Base

Notably, Turkey's foreign trade deficit with Russia is equal to 23 percent of Turkey's current account deficit; trade deficit in the raw materials from Russia is 26 percent of Turkey's current account deficit. As the table 3 shows, Russia has 11 percent share in Turkey's total import but only holds a 4 percent share in Turkey's total export (TUIK, Foreign Trade Data). Turkey needs to reduce dependence on imports of raw material from Russia or must start a trade attack. Because of the increase in the prices of oil, Russia's share would increase in the foreign trade deficit of Turkey. Kazakhstan is another 
member of Eurasec which also exports oil and natural gas to Turkey. Belarus, Kyrgyzstan and Tajikistan bilateral trades with Turkey are not excess.

Turkey carries out exports consumption goods to Eurasec region and import raw materials (oil, natural gas) from Eurasec region. The gap between exports and imports among Turkey and Eurasec region are in increase both numerically and proportionally. To settle the trade deficit between Turkey and Region holds a great importance.

\section{CONCLUSION}

When the economic structures of Eurasec members are examined, it seems that these countries are exporters of raw materials, intermediate goods and energy. Economic development and progress of these countries are based on these exports. Despite this, especially importation of products and consumer products are the common features of these mentioned countries. In this respect, the general economic structure of region and the foreign trade structure are completely the opposite of improved economies.

When the current economic structures are considered, we can see that Turkey maintains a strong position in Eurasec region at basic importation products like food, textile, chemistry, machine and readymade. It is known that sovereignty of retailing sector in region is about 1 billion dollar and $\% 80$ of this consumption is taken with importation. Thus, there is a high chance that Turkey could sell retail food, textile and confection products to these regions by considering the consumption tendency, needs and region's population. Another area that is seen as opportunity for Turkey is the substructure deficiencies which union countries have. In that point, especially in the construction sector, Turkey is very compelling and there exists good opportunities. On the other hand, more than $\% 95$ of importation of Turkey from this region is formed of especially gasoline, natural gas, raw materials and intermediate goods. Therefore it could be claimed that this bilateral trade could improve in favour of Turkey.

Geographical proximity between Eurasec countries and Turkey can be a major advantage for counter trade. However, one of the biggest problems of trade that is done with Eurasec countries in current situation is the transportation cost and toll. In this respect, Kars-Tbilisi rail line and Istanbul-Almaty container lines should be processed but to actualize this necessary rehabilitations should be built in order to work productively. Considering the EU customs responsibility of Turkey and the current situation of Eurasec customs union, it is presumed that providing mutual customs tariffs and quota exemption are in favour of Turkey.

In conclusion, after considering the economic improvement level with resolution advisories, Eurasec countries could open strategic foreign market for Turkey. 


\section{REFERENCES}

Abrego, Lisandro. Raymond Rieazman and John Whalley (2005), "Computation and the Theory of Customs Unions", CESifo Economic Studies, Vol.51, 1/2005, 117-132.

Bhagwati, Jagdish and Arvind Panagariya (1996), "The Theory of Preferential Trade Agreements: Historical Evaluation and Current Trend", The American Economic Review, 86(2), 82-87.

CEIC Data, Foreign Trade Data, Belarus, Kazakhstan, Kyrgyzstan, Russian, Tajikistan.

CIA, Factbook, Belarus, Kazakhstan, Kyrgyzstan, Russian, Tajikistan Country Profile.

EDP, Eurasian Development Bank, http://www.eabr.org/eng

Ertürk, Emin (2010), Uluslararası İktisat, [International Economics], Alfa Press, Istanbul.

Eurasianhome, Eurasian Economic Community (EAEC).

$\mathrm{http} / / / \mathrm{www}$.eurasianhome.org/xml/t/databases.xml?lang=en\&nic=databases\&intorg=3\&pid=25

http://www.worldtradelaw.net/fta/agreements/eaecfta.pdf

Foreign Economic Relations Board (February 2007), Foreign Relations Committee, Kazakhstan Country Journal, Istanbul.

Foreign Economic Relations Board (June 2009), Foreign Relations Committee, Tajikistan Country Journal, Istanbul.

Foreign Economic Relations Board (May 2009), Foreign Relations Committee, Kyrgyzstan Country Journal, Istanbul.

Frankel, Jeffrey A. and etc. (1996), "Regional Trading Arrangements: Natural or Supernatural?" The American Economic Review, 86(2), 52-56.

Garcia, Juan Fernandez Garcia, Jess Clayton and Christopher Hobley (Ed.) (2004), The Student's Guide To European Integration, Polity Press, UK.

ICI, Istanbul Chamber of Industry (April 2010), Russia Country Report, http://www.aia-istanbul.org/ files/bilgibankasi/pazarlar/ulkeler/russia_ulkeraporu.pdf

Karluk, Ridvan (1996), Uluslararası Ekonomi, [International Economy], Beta Press, Istanbul.

Kiliç, Ramazan (2002), Türkiye- AB İlişkileri ve Gümrük Birliği, [Turkey-EU Relations and Customs Union], Siyasal Kitabevi, Siyasal Press, Ankara.

Kindleberger, Charles P. (1958), International Economics, Uluslararası İktisat, (Trans. N. Serin), Sevinç Matbaası, Ankara, 1970.

Krishna, Pravin (2003), “Are Regional Trading Partners Natural?”, Journal of Political Economy, 111 (1), 202-231.

Krugman, Paul (1991), "Increasing Returns and Economic Geography”, The Journal of Political Economy, vol.99, Issue.3 (Jun.1991), 483-499.

Meade, James E. (1955), The Theory of Customs Unions, North-Holland, Amsterdam.

Moldosanov, Janybek (2005), Prospects for Regional Integration in Central Asia: The Case of EURASEC, Unpublished Master Thesis, Marmara Universitesi Avrupa Topluluğu Enstitüsü.

Norling, Nicklas and Niklas Swanstrim (2007), "The Virtues and Potential Gains of Continental Trade in Eurasia", Asian Survey,.47: 3, 351-373.

Öngel, Volkan (2010), "An Alternative Foreign Trade Market for Turkey: The Eurasian Economic Community”, International Conference On Eurasian Economies 2010, Istanbul.

Panagariya, Arvind (1997), "Preferential Trading and the Myth of Natural Trading Partners", Japan and the World Economy, 9, 471-489.

Schiff, Maurice (1997), "Small is Beautiful Preferential Trade Agreement and the Impact of Country Size, Market Share, Efficiency and Trade Policy", Journal of Economic Integration, 12(3), 359-387.

Schiff, Maurice (1999), “Will the Real Natural Trading Partner Please Stand Up?”, World Bank Policy Research Working Paper, No.2161. 
Shadikhodjaev, Sherzod (2009), "Trade Integration in the CIS Region: A Thorny Path towards a Customs Union”, Journal of International Economic Law, 12(3), 555-578.

Tinbergen, Jan (1965), International Economic Integration, Elsevier Publishing Co., Amsterdam.

TUIK, Turkey Statistics Corporation (2010), Foreign Trade Statistics, http://www.tuik.gov.tr/ VeriBilgi.do?tb_id=12\&ust_id=4

Under secretariat of the Prime Ministry for Foreign Trade, Export Promotion Center of Turkey (ÝGEME), (2008), Belarus Country Report, Ankara.

Viner, Jacob (1950), The Customs Union Issue, Carnegie Endowment for International Peace, New York.

Wonnacott, Paul and Mark Lutz (1989), "Is There a Case for Free Trade Areas", in Schott, J. (Ed.), Free Trade Areas and US Trade Policy, Institute for International Economics, Washington, D.C.

Yıldırım Ertugrul and Cihan Dura (2007), “Gümrük Birliği’nin Türkiye Ekonomisi Üzerindeki Etkileri Konusunda Literatüre Bir Bakış”, Erciyes University IIBF Journal, 28: January-June 2007. 